University of Nebraska - Lincoln

DigitalCommons@University of Nebraska - Lincoln

Agronomy \& Horticulture -- Faculty Publications

Agronomy and Horticulture Department

2017

\title{
The Impact of Continuous Living Cover on Soil Hydrologic Properties: A Meta-Analysis
}

Andrea D. Basche

University of Nebraska-Lincoln, abasche2@unl.edu

Marcia DeLonge

Union of Concerned Scientists

Follow this and additional works at: https://digitalcommons.unl.edu/agronomyfacpub

Part of the Agricultural Science Commons, Agriculture Commons, Agronomy and Crop Sciences Commons, Botany Commons, Horticulture Commons, Other Plant Sciences Commons, and the Plant Biology Commons

Basche, Andrea D. and DeLonge, Marcia, "The Impact of Continuous Living Cover on Soil Hydrologic Properties: A Meta-Analysis" (2017). Agronomy \& Horticulture -- Faculty Publications. 1131. https://digitalcommons.unl.edu/agronomyfacpub/1131

This Article is brought to you for free and open access by the Agronomy and Horticulture Department at DigitalCommons@University of Nebraska - Lincoln. It has been accepted for inclusion in Agronomy \& Horticulture -Faculty Publications by an authorized administrator of DigitalCommons@University of Nebraska - Lincoln. 


\section{The Impact of Continuous Living Cover on Soil Hydrologic Properties: A Meta-Analysis}

\author{
Andrea Basche* \\ Marcia DeLonge \\ Union of Concerned Scientists \\ 1825 K. Street NW, Suite 800 \\ Washington, DC 20006
}

\section{Core Ideas}

- Meta-analysis compared soil hydrology in perennial- and annualbased crop systems.

- Continuous living cover practices significantly increased porosity, field capacity.

- There may be a greater effect in drier environments and sandier soils.

- Experiments in place longer than ten years also tended to increase the properties.

- Results suggest how continuous living cover can negate rainfall variability impacts.
Increased rainfall variability due to climate change threatens the efficacy of critical soil ecosystem services. One strategy to negate effects of too much or not enough rainfall is to improve soil water properties. Practices that offer "continuous living cover" can enhance soil water storage and other soil hydrologic properties relative to annual crop systems, but to what extent such benefits can accrue, under different conditions, remains under-quantified. To address these uncertainties, we conducted a meta-analysis that included 27 studies representing 93 paired observations measuring two soil hydrologic properties: porosity and the water retained at field capacity. All experiments compared the impact of continuous living cover practices (cover crops, perennial grasses, agroforestry and managed forestry) to annual crop controls. Continuous living cover significantly increased total porosity $(8.0 \pm 2.2 \%)$ and the water retained at field capacity $(9.3 \pm 2.7 \%)$. There was some evidence indicating improved effects in relatively drier environments $(<900 \mathrm{~mm}$ annual rainfall) and in regions with sandier soils. There was no evidence of publication bias, and a sensitivity analysis indicated that overall effects were robust. The similar direction and magnitude of improvements in both properties could be evidence of similar physical and chemical processes impacted by the continuous presence of living roots. Overall, our findings suggest that continuous living cover practices may be a potential adaptation strategy to combat rainfall variability. Furthermore, properties such as porosity and field capacity may serve as proxies to determine how management influences soil water and heath more broadly.

I mproving soil health and resilience into the future is a critical priority for 21 st century agriculture, given increased demands on agriculture, including climate change (Amundson et al., 2015). As a result of a warming atmosphere, increased rainfall variability is already measured in the recent record and is projected to intensify into the future (IPCC, 2013; Pryor et al., 2014). Increased rainfall variability threatens the efficacy of key soil ecosystem services that are necessary for both crop production and environmental protection, including erosion prevention, nutrient loss reduction and water storage. Agricultural practices that focus on enhancing soil water storage have multiple co-benefits that might also reduce environmental damages and crop losses through better maintenance of soil water (Sposito, 2013; Stewart and Peterson, 2015).

One approach to regenerating soil health is the adoption of cropping practices that ensure "continuous living cover" of the soil, or the presence of live roots in the ground throughout the entire year (Jordan and Warner, 2010). This approach is in contrast to annual cropping systems that typically have extended periods of bare soil, and it affords the direct benefits of preventing nutrient loss (through plant uptake) as well as erosion protection (through minimizing the impact of rainfall and wind). Continuous living cover practices also contribute to the chemical and physical processes that provide enhanced soil water storage, including increasing organic matter and improving soil aggregation (Hudson, 1994; Emerson, 1995).

Soil Sci. Soc. Am. J. 81:1179-1190

doi:10.2136/sssaj2017.03.0077

Received 11 Mar. 2017

Accepted 17 May 2017.

*Corresponding author: (andrea.basche.phd@gmail.com).

(C) Soil Science Society of America. This is an open access article distributed under the CC BY

license (https://creativecommons.org/licenses/by/4.0/). 
Continuous living cover can further improve the water balance in agricultural systems by facilitating water infiltration and reducing soil evaporation as well as runoff. Encouraging evidence from global modeling efforts also indicates that agricultural water management approaches that reduce soil evaporation and water runoff can boost production to levels comparable to gains from irrigation (Rost et al., 2009; Jägermeyr et al., 2016). Although it is well understood that continuous living cover can improve soil hydrology, the potential for improvement from specific practices in different environments remains under-quantified.

Investigating the soil water impacts of agricultural management is complex, in part because there is no standard method for measuring soil wetness or for reporting results (Hillel, 1998). For example, many studies report soil water content collected for discrete points in time either through gravimetric or volumetric measurements, or as continuous measurements from a variety of in situ instruments. Further, the soil water status of a field is highly variable both in space and time (Russo and Bresler, 1981; Greminger et al., 1985), complicating a universal interpretation of how management impacts these measurements. Other soil hydrologic properties such as aggregate stability, hydraulic conductivity, plant available water, water retained at field capacity, and porosity are far less likely to change on a day-to-day or hour-to-hour basis and may be better suited to investigate how soil management, such as crop and tillage selection, influences soil water. As a result, hydrologic properties such as available water content and aggregate stability are a few of the indicators included in soil health assessments, such as the Soil Management Assessment Framework and the Cornell Soil Health Framework (Andrews et al., 2004; Moebius-Clune et al., 2016). Although they represent more indirect measures of soil water conditions, these soil properties do provide proxies of management impacts that can be analyzed by meta-analysis, a powerful quantitative tool to summarize disparate experiments to better understand broader treatment effects (Philibert et al., 2012).

The goal of this analysis is to provide a quantitative summary of how practices that promote continuous living cover including cover crops, perennial crops, agroforestry and managed forestry, improve two key soil hydrologic properties that relate to water storage. The soil properties focused on in this analysis were total porosity and the water retained at field capacity. First, total porosity provides a simple quantification of the amount of space available for fluid movement in soil (Nimmo, 2004). The water retained at field capacity, or the upper end of plant available water, is commonly used in agricultural research and has important implications for crop production (Hillel, 1998). These two properties were also chosen because they are commonly used in agricultural and hydrological models, tools which can provide a link between microscale soil processes and broader watershed-scale impacts over space and time. This analysis also investigated the role of additional variables, including study length (i.e., number of years since treatment was implemented), annual precipitation and soil type, to understand how these characteristics modulate treatment ef- fects, and in turn, determine if there are conditions that might enable the greatest hydrologic benefit from continuous living cover.

\section{MATERIALS AND METHODS Database Development}

The goal of this analysis was to understand the impact of continuous living cover on soil hydrologic properties in agricultural systems using a meta-analysis approach. Therefore, the first step was to develop a database of studies that could be included in the analysis. The two major criteria for database inclusion were (i) Studies compared land managed with continuous plant growth (including cases of actively restored perennial landscapes) versus annual crop systems that did not include continuous plant cover and (ii) Studies measured at least one of two indicators of soil hydrology: water retained at field capacity (the maximum level of plant available soil water, hereafter referred to as field capacity) or total porosity (the maximum volume of water that soil can hold). Several different treatment practices representing continuous living cover were sought for inclusion in the database:

1. Cover crops, where a cover crop was grown in between the harvest of annual cash crops (compared to leaving soil uncovered in the control treatment)

2. Perennial grasses, including grazing systems with either native or cultivated grasses, Conservation Research Program (CRP) protected conservation lands, perennial bioenergy or forage crops

\section{Agroforestry systems}

\section{Managed forestry systems}

The EBSCO Discovery Service (https://www.ebscohost. com/discovery/content) was the primary search engine used to compile the database for this analysis. It searches a comprehensive collection of titles, including more than 23,000 publications from databases such as JSTOR and publishers such as Wiley, Elsevier, Springer-Nature, IOP, Royal Society, Oxford, Cambridge, Thomson Reuters, AAAS, and the American Society of Agronomy. The EBSCO Discovery Service matches on subject headings, keywords, and abstracts, making it an ideal search engine for building a database targeted to the highly specific question in this analysis. The keyword search included descriptors of the soil properties (given the multiple terms that might be used to describe field capacity) as well as the different continuous living cover practices. The search terms included were: water retention OR field capacity OR moisture retention OR porosity AND perennial W1 grass* OR cover crop* OR agroforest* OR forest* ${ }^{*}$. These keyword terms found $>400$ studies, of which 25 ultimately fit our criteria.

To supplement the EBSCO Discovery Service search, the USDA-NRCS Soil Health Literature Database (USDANRCS, 2016) was used to find additional research papers. This database is an ongoing effort of the NRCS Soil Health Division to categorize the impact of conservation practices on soil properties and uses large search databases (including Google Scholar) to find papers. It is updated regularly by staff and currently includes 
more than 300 peer-reviewed references. The database allows users to search specific soil properties, including water retention and soil porosity, as well as specific treatments based on established NRCS practice codes. From this search, we added two additional studies, for a total of 27 studies representing 93 separate paired observations for both soil properties analyzed. Only three studies included field measurements of both properties.

Several studies had complex treatment or control scenarios and were entered into the database only after careful consideration. Some experimental designs (i.e., with a variety of cover crop or perennial grass treatments) allowed for multiple comparisons to be created within individual experiments. If an experiment included multiple treatments that could be considered a control (i.e., different annual cropping systems; Tables 1 and 2), these were averaged to represent one control treatment. Also, for some of the most complex studies, it was not possible to develop comparisons between treatments that solely tested the isolated effect of the continuous living cover treatment to an annual cropping system control. For example, several experiments included perennial grasses with livestock grazing compared to annual crops, such that the inclusion of grazing animals was a confounding factor. While not ideal, these studies were maintained in the database as they still represented important differences between annual and perennial based systems.

Steps were taken to ensure that field measurements were extracted from each paper as consistently as possible. For example, for the field capacity measurements, if authors described a specific potential pressure typical for their location, then this was the potential pressure that was utilized for the database. When experiments did not assign a specific potential pressure associated with field capacity, potentials in the range of -10 to $-33 \mathrm{kPa}$ were selected, and if multiple measurements in this range were reported, they were averaged (Hillel, 1998; Table 2). This analysis specifically focused on the wetter range of the water retention curve because the pore sizes that affect this range are the ones understood to be affected by management (Kay, 1998). For porosity, only studies that included measurements for total porosity, as opposed to measurements of only macroporosity, microporosity, or porosities associated with different particle and aggregate sizes, were included in the database. This was done in an attempt to keep the comparison as standardized as possible across the range of soil textures. If experiments measured properties more than once in a season or for multiple depths, these measurements were averaged

Table 1. Studies measuring total porosity in the meta-analysis database.

\begin{tabular}{|c|c|c|c|c|c|}
\hline Location & Treatment category & Control & Treatment & Experimental design & Reference \\
\hline Denmark & Cover crop & Spring barley & With radish cover crop & Split Plot, 3 Replications & $\begin{array}{l}\text { Abdollahi and } \\
\text { Munkholm } 2014\end{array}$ \\
\hline Nigeria & Perennial grass & $\begin{array}{l}\text { Cereal-legume } \\
\text { continuous cropping }\end{array}$ & $\begin{array}{l}\text { Perennial pasture grasses with } 2 \\
\text { mo controlled grazing }\end{array}$ & $\begin{array}{l}5 \text { adjacent } \sim 2.5 \text { ha field } \\
\text { sites, sampled nine } \\
\text { locations from each site }\end{array}$ & Abu 2013 \\
\hline France & Cover crop & $\begin{array}{l}\text { Barley, pea and wheat } \\
\text { without cover crops }\end{array}$ & $\begin{array}{l}\text { With legume cover crops, } \\
\text { managed as living mulches }\end{array}$ & $\begin{array}{l}\text { Sampled from } 6 \text { locations } \\
\text { in each treatment }\end{array}$ & Carof et al. 2007 \\
\hline Italy & Perennial grass & Continuous wheat & Perennial pasture & 2 Replications & Chisci et al. 2001 \\
\hline Brazil & Cover crop & $\begin{array}{l}\text { Fallow, ruzigrass, } \\
\text { sorghum }\end{array}$ & $\begin{array}{l}\text { With sorghum-sudangrass, } \\
\text { sunhemmp, millet cover crops }\end{array}$ & $\begin{array}{l}\text { Randomized Complete } \\
\text { Block, } 4 \text { Replications }\end{array}$ & Garcia et al. 2013 \\
\hline Iran & Perennial grass & Continuous wheat & Pasture with livestock & $\begin{array}{l}\text { Sampled from } 6 \text { points in } \\
\text { each land use }\end{array}$ & Haghighi et al. 2010 \\
\hline Ethiopia & Agroforestry & $\begin{array}{l}\text { Maize-based } \\
\text { conventional tillage }\end{array}$ & $\begin{array}{l}\text { Agroforestry based conservation } \\
\text { with livestock }\end{array}$ & $\begin{array}{l}\text { Sampled from } 4 \text { areas in } \\
\text { two adjacent fields }\end{array}$ & Ketema and Yimer 2014 \\
\hline China & Perennial grass & Annual oats & $\begin{array}{l}\text { Perennial pasture with livestock } \\
\text { grazing }\end{array}$ & 3 Replications & Li et al. 2007 \\
\hline Pakistan & Cover crop & Cotton-wheat & Berseem green manure & 4 Replications & $\begin{array}{l}\text { Mahmood-ul-Hassan et } \\
\text { al. } 2013\end{array}$ \\
\hline Australia & $\begin{array}{l}\text { Perennial grass, } \\
\text { Agroforestry }\end{array}$ & $\begin{array}{l}\text { Continuous annual } \\
\text { cropping }\end{array}$ & $\begin{array}{l}\text { Perennial pasture \& alley } \\
\text { cropping }\end{array}$ & $\begin{array}{l}2 \text { Replications of pasture, } \\
3 \text { Replications of alley } \\
\text { cropping and continuous } \\
\text { annual cropping }\end{array}$ & Mele et al. 2003 \\
\hline Canada & Cover crop & Continuous corn & $\begin{array}{l}\text { Corn, corn, oats, barley with } \\
\text { red clover cover crop }\end{array}$ & $\begin{array}{l}\text { Randomized Split Plot, } 4 \\
\text { Replications }\end{array}$ & Munkholm et al. 2013 \\
\hline Ghana & Cover crop & Maize-fallow & $\begin{array}{l}\text { With mucuna, stylosanthes and } \\
\text { mimosa cover crops }\end{array}$ & Split Plot, 4 Replications & Nyalemegbe et al. 2011 \\
\hline North Carolina, USA & $\begin{array}{l}\text { Perennial grass, } \\
\text { Forestry }\end{array}$ & $\begin{array}{l}\text { Conventionally tilled } \\
\text { corn, peanuts, cotton, } \\
\text { soybeans }\end{array}$ & $\begin{array}{l}\text { Integrated livestock and pasture, } \\
\text { black walnut plantation forestry } \\
\text { woodlot }\end{array}$ & $\begin{array}{l}3 \text { Replicated Blocks (8-ha } \\
\text { each) with five sub-plots } \\
\text { for different treatments }\end{array}$ & Raczkowski et al. 2012 \\
\hline Argentina & Perennial grass & $\begin{array}{l}\text { Average of corn and } \\
\text { soybean treatments }\end{array}$ & Pasture & $\begin{array}{l}\text { Sampled from } 5 \text { locations } \\
\text { in each treatment }\end{array}$ & Sasal et al. 2010 \\
\hline Brazil & Agroforestry & Corn-soybean & $\begin{array}{l}\text { Silvopasture, agro-silvopasture } \\
\text { with livestock }\end{array}$ & $\begin{array}{l}\text { Adjacent fields, sampled } \\
\text { from four transects per } \\
\text { field }\end{array}$ & Silva et al. 2011 \\
\hline Illinois, USA & Cover crop & Corn-soybean & $\begin{array}{l}\text { With rye, vetch, rye + vetch } \\
\text { cover crop }\end{array}$ & $\begin{array}{l}\text { Randomized Complete } \\
\text { Block, } 4 \text { replications }\end{array}$ & Villamil et al. 2006 \\
\hline
\end{tabular}


Table 2. Studies measuring the water retained at field capacity in the meta-analysis database.

\begin{tabular}{|c|c|c|c|c|c|c|}
\hline Location & $\begin{array}{l}\text { Treatment } \\
\text { category }\end{array}$ & Control & Treatment & $\begin{array}{l}\text { Experimental } \\
\text { design }\end{array}$ & $\begin{array}{l}\text { Pressure reported for } \\
\text { volumetric water content used } \\
\text { in response ratio }\end{array}$ & Reference \\
\hline Nigeria & $\begin{array}{l}\text { Perennial } \\
\text { grass }\end{array}$ & $\begin{array}{l}\text { Cereal-legume } \\
\text { continuous cropping }\end{array}$ & $\begin{array}{l}\text { Perennial pasture } \\
\text { grasses with } 2 \text { mo } \\
\text { controlled grazing }\end{array}$ & $\begin{array}{l}5 \text { adjacent } \sim 2.5 \text { ha field } \\
\text { sites, sampled nine } \\
\text { locations from each site }\end{array}$ & $\begin{array}{l}\text { Assigned }-10 \mathrm{kPa} \text { as Field } \\
\text { Capacity }\end{array}$ & Abu 2013 \\
\hline $\begin{array}{l}\text { lowa, } \\
\text { USA }\end{array}$ & Cover crop & Corn-soybean & With rye cover crop & $\begin{array}{l}\text { Randomized Complete } \\
\text { Block, } 4 \text { Replications }\end{array}$ & $\begin{array}{l}\text { Assigned }-33 \mathrm{kPa} \text { as Field } \\
\text { Capacity }\end{array}$ & $\begin{array}{l}\text { Basche et al. } \\
2016\end{array}$ \\
\hline $\begin{array}{l}\text { Missouri, } \\
\text { USA }\end{array}$ & $\begin{array}{l}\text { Perennial } \\
\text { grass }\end{array}$ & $\begin{array}{l}\text { Corn-soybean (average } \\
\text { of till and no till } \\
\text { treatments) }\end{array}$ & $\begin{array}{l}\text { Timothy grass and } \\
\text { restored prairie }\end{array}$ & $\begin{array}{l}\text { Sampled from } 6 \\
\text { replications in adjacent } \\
\text { fields }\end{array}$ & $\begin{array}{l}\text { Reported } \\
-10 \mathrm{kPa},-20 \mathrm{kPa} \text {, } \\
-33 \mathrm{kPa} \text {, averaged values }\end{array}$ & $\begin{array}{l}\text { Chandrasoma } \\
\text { et al. } 2016\end{array}$ \\
\hline $\begin{array}{l}\text { Missouri, } \\
\text { USA }\end{array}$ & $\begin{array}{l}\text { Cover crop, } \\
\text { Perennial } \\
\text { grass }\end{array}$ & $\begin{array}{l}\text { Mulch-till } \\
\text { corn-soybean }\end{array}$ & $\begin{array}{l}\text { No-till corn-soybean- } \\
\text { wheat with red clover, } \\
\text { CRP, pasture }\end{array}$ & $\begin{array}{l}\text { Randomized Complete } \\
\text { Block, } 3 \text { Replications }\end{array}$ & $\begin{array}{l}\text { Reported }-10 \mathrm{kPa} \text {, } \\
-20 \mathrm{kPa},-33 \mathrm{kPa} \text {, } \\
\text { averaged values }\end{array}$ & $\begin{array}{l}\text { Jiang et al. } \\
2007\end{array}$ \\
\hline $\begin{array}{l}\text { Tennessee, } \\
\text { USA }\end{array}$ & Cover crop & Cotton & $\begin{array}{l}\text { With rye-vetch cover } \\
\text { crop }\end{array}$ & 4 Replications & $\begin{array}{l}\text { Reported }-10 \mathrm{kPa},-15 \\
\mathrm{kPa},-20 \mathrm{kPa},-30 \mathrm{kPa} \text {, } \\
\text { averaged values }\end{array}$ & $\begin{array}{l}\text { Keisling et al., } \\
1994\end{array}$ \\
\hline $\begin{array}{l}\text { Georgia, } \\
\text { USA }\end{array}$ & Forestry & $\begin{array}{l}\text { Corn-soybean } \\
\text { conventional tillage }\end{array}$ & $\begin{array}{l}\text { Long leaf pine, planted } \\
\text { pine }\end{array}$ & $\begin{array}{l}\text { Randomized complete } \\
\text { block, } 3 \text { Replications }\end{array}$ & $\begin{array}{l}\text { Assigned }-10 \mathrm{kPa} \text { as Field } \\
\text { Capacity }\end{array}$ & $\begin{array}{l}\text { Levi et al. } \\
2010\end{array}$ \\
\hline Zimbabwe & Agroforestry & Continuous maize & $\begin{array}{l}\text { Improved fallow w/ } \\
\text { acacia \& sesbania }\end{array}$ & $\begin{array}{l}\text { Randomized Complete } \\
\text { Block, } 3 \text { Replications }\end{array}$ & $\begin{array}{l}\text { Reported volumetric } \\
\text { water content between } \\
-5 \mathrm{kPa} \&-33 \mathrm{kPa} \text {, } \\
\text { averaged values }\end{array}$ & $\begin{array}{l}\text { Nyamadzawo } \\
\text { et al. } 2012\end{array}$ \\
\hline $\begin{array}{l}\text { Louisiana, } \\
\text { USA }\end{array}$ & Cover crop & Cotton & $\begin{array}{l}\text { With common vetch or } \\
\text { hairy vetch cover crops }\end{array}$ & 3 Replications & $\begin{array}{l}\text { Assigned } 1 / 3 \text { atm as Field } \\
\text { Capacity }\end{array}$ & $\begin{array}{l}\text { Patrick et al. } \\
1957\end{array}$ \\
\hline $\begin{array}{l}\text { North } \\
\text { Carolina, } \\
\text { USA }\end{array}$ & $\begin{array}{l}\text { Perennial } \\
\text { grass, } \\
\text { Forestry }\end{array}$ & $\begin{array}{l}\text { Corn, peanuts, cotton, } \\
\text { soybeans (average } \\
\text { of till and no till } \\
\text { treatments) }\end{array}$ & $\begin{array}{l}\text { Integrated livestock and } \\
\text { pasture, black walnut } \\
\text { plantation forestry } \\
\text { woodlot }\end{array}$ & $\begin{array}{l}3 \text { Replicated Blocks (8-ha } \\
\text { each) with five sub-plots } \\
\text { for different treatments }\end{array}$ & $\begin{array}{l}\text { Assigned }-10 \mathrm{kPa} \text { as Field } \\
\text { Capacity }\end{array}$ & $\begin{array}{l}\text { Raczkowski } \\
\text { et al. } 2012\end{array}$ \\
\hline $\begin{array}{l}\text { Texas, } \\
\text { USA }\end{array}$ & $\begin{array}{l}\text { Perennial } \\
\text { grass, Cover } \\
\text { crop }\end{array}$ & $\begin{array}{l}\text { Sorghum-wheat } \\
\text { conventional tillage }\end{array}$ & CRP, Grazed grassland & $\begin{array}{l}\text { Sampled } 3 \text { different } \\
\text { locations according to } \\
\text { soil type in adjacent fields }\end{array}$ & $\begin{array}{l}\text { Reported }-10 \mathrm{kPa},-30 \\
\mathrm{kPa} \text {, averaged values }\end{array}$ & $\begin{array}{l}\text { Schwartz et } \\
\text { al. } 2003\end{array}$ \\
\hline Brazil & Agroforestry & Corn-soybean & $\begin{array}{l}\text { Silvopasture, agro- } \\
\text { silvopasture with } \\
\text { livestock }\end{array}$ & $\begin{array}{l}\text { Adjacent fields, sampled } \\
\text { from four transects per } \\
\text { field }\end{array}$ & $\begin{array}{l}\text { Assigned } 0.01 \mathrm{MPa} \text { as } \\
\text { Field Capacity }\end{array}$ & $\begin{array}{l}\text { Silva et al. } \\
2011\end{array}$ \\
\hline India & Cover crop & Rice-wheat & $\begin{array}{l}\text { With sesbania green } \\
\text { manure }\end{array}$ & $\begin{array}{l}\text { Randomized Complete } \\
\text { Block, } 3 \text { Replications }\end{array}$ & $\begin{array}{l}\text { Assigned } 0.3 \text { bars as } \\
\text { Field Capacity }\end{array}$ & $\begin{array}{l}\text { Walia et al. } \\
2010\end{array}$ \\
\hline Nigeria & Cover crop & Maize-cassava-cowpea & With cover crops & $\begin{array}{l}\text { Randomized Complete } \\
\text { Block, } 3 \text { Replications }\end{array}$ & $\begin{array}{l}\text { Assigned pF } 2.5 \text { as Field } \\
\text { Capacity }\end{array}$ & $\begin{array}{l}\text { Wilson et al. } \\
1982\end{array}$ \\
\hline China & Forestry & $\begin{array}{l}\text { Wheat, rapeseed, } \\
\text { canola }\end{array}$ & Afforestation & $\begin{array}{l}5 \text { samples taken from } \\
\text { adjacent fields }\end{array}$ & $\begin{array}{l}\text { Assigned pF } 2.5 \text { as Field } \\
\text { Capacity }\end{array}$ & Yu et al. 2015 \\
\hline
\end{tabular}

to create one comparison per treatment. Several studies reported measurements that were taken at the end of a season for multiple years and these were counted as separate paired observations.

Additional variables were extracted from studies for more detailed analysis. These variables enabled a comparison of subsets of data including presence or absence of livestock on treatment plots, study length (i.e., number of years the treatment was in place), soil texture, and annual precipitation. For length of study, texture and precipitation data, thresholds for subgroups were set to create as equally sized comparison groups as possible. When soil texture and precipitation information were not available, soil texture was located from the Web Soil Survey (Soil Survey Staff, 2012) and precipitation data from the National Oceanic and Atmospheric Administration's (NOAA) Global Historical Climatology Network database (Menne et al., 2012).

\section{Statistical Analysis}

Response ratios were calculated as the ratio of the soil water property measured in areas with continuous living cover treatments as compared in annual cropping system controls. The natural $\log$ of the response ratio was calculated for the two soil properties separately, and used as the basis for all statistical analyses (Eq. [1]) (Hedges et al., 1999). For meta-analysis, a weighting factor is typically developed to give more weight to studies with greater levels of precision or lower within study variability (Philibert et al., 2012). As many of the experiments in this database did not provide measurements of within study variability (standard deviations or standard errors), the number of experimental replications were used as an alternative method to develop a weighting factor (Eq. [2]) (Adams et al., 1997). In studies with experimental designs that did not include true replication (i.e., relying instead on multiple subsamples from different treatments), a replication size of " 1 " was assigned to create a lesser weight for those experiments in the calculation of mean effect sizes (Tables 1 and 2). 
The primary statistical analysis was conducted using $\mathrm{R}$ ( $\mathrm{R}$ Core Team, 2016). A mixed effects model (lmer4 package) was used to calculate mean effects, including a random effect of study and the weighting factor of experimental replications. The random effect of study is similar to a "block" effect, accounting for similarities in environments when more than one response ratio was available for one study (St. Pierre, 2001; Eldridge et al., 2016). In addition to calculating overall mean effects of treatments for each soil water property, studies were analyzed in groups according to soil texture, annual precipitation, or the inclusion versus exclusion of livestock; for the statistical analysis, these groups were treated as fixed effects. If $95 \%$ confidence interval did not cross zero, results were considered significant. For ease of interpretation, the log response ratios (LRR) were back transformed and converted to percentages (Eq. [3]).

$$
\mathrm{LRR}=\ln \frac{\text { Experimental Trt } \mathrm{X}}{\text { Control } \mathrm{X}}
$$

where $\mathrm{X}$ is either porosity or field capacity

$$
\begin{aligned}
& W_{i}=\frac{\text { Experimental Reps }{ }^{*} \text { Control Reps }}{\text { Experimental Reps }+ \text { Control Reps }} \\
& \text { Percent change }=[\operatorname{Exp}(\text { LRR })-1]^{*} 100
\end{aligned}
$$

Publication bias was assessed by evaluating histograms to determine if there were differences in the number of studies published based on effect sizes, which would reflect a preference against publishing studies that do not show significant positive or negative effects (Rosenberg et al., 2000). Histograms were the most effective way to address publication bias in this analysis; funnel plots comparing effect sizes to sample sizes are sometimes used to evaluate publication bias in meta-analysis, where it would be expected that greater sample sizes have lower variance in effect sizes (Møller and Jennions, 2001). However, in this analysis where sample sizes are represented by experimental replications, there was not a wide enough range to create meaningful funnel plots based on this metric. Sensitivity analysis was performed using a Jackknife technique where individual studies were removed and the overall effect size of continuous living cover practices on both porosity and field capacity were recalculated using the same statistical model (Philibert et al., 2012).

\section{RESULTS}

The change in total porosity in response to continuous living cover ranged widely and was sensitive to several variables (Fig. 1a, 1b). The overall mean percent improvement in total porosity with continuous living cover was $8.0 \pm 2.2 \%$ (95\% confidence interval 3.7-12.3\%). Experiments in regions with relatively less rainfall ( $<900 \mathrm{~mm}$ ) had a significant improvement in total porosity with continuous living cover $(11.1 \pm 3.2 \%, n=16$ from 8 studies), as did those without livestock included $(10.5 \pm 2.6 \%$, $n=28$ from 10 studies). In studies that did include livestock on treatment plots, there was a small but significant reduction in porosity $(-5.4 \pm 2.5 \%, n=18$ from 7 studies $)$. There was not a clear pattern for the impact of soil texture on the response ratios for porosity changes with continuous living cover treatments.

The change in field capacity with continuous living cover was also variable and depended on several factors, but in slightly different ways as compared to porosity (Fig. 1a, 1c). The overall mean effect was $9.3 \pm 2.7 \%$ (95\% confidence interval $4.0-14.5 \%$ ). Similar to the observed porosity effects, there was a significant improvement in field capacity in response to continuous living cover in drier environments (<900 mm annual rainfall, $12.7 \pm 4.3 \%, n$ $=14$ from 6 studies), whereas there were no significant effects in wetter regions. Also, there was again a significant improvement found in studies without livestock $(6.8 \pm 3.0 \%, n=33$ from 12 studies). On the other hand, field capacity also significantly increased, and by a larger amount $(11.9 \pm 3.3 \%, n=14$ from 4 studies), in the experiments with livestock, which was not the case for porosity. In addition to these differences, there was a more distinct effect of soil texture. Experiments with sandier soils (>65\% sand, mean $=10.1 \pm 5.2 \%, n=31$ from 7 studies) showed a more positive trend toward greater improvements. Soils with more silt and clay as well as wetter environments did not show increases in the water retained at field capacity with continuous living cover.

From the experiments included in this analysis, there was not a conclusive effect of study length. For total porosity, the relatively shorter studies had a slightly larger mean improvement (Fig. 1b; $8.0 \pm 2.7 \%$ for the studies $<7$ yr versus $-0.1 \pm 4.7 \%$ for the studies $>7 \mathrm{yr}$ ). For field capacity, the longer studies had a slightly greater mean improvement but the response was not significant in either subgroup (Fig. 1c; $3.3 \pm 4.1 \%$ for the studies $<7$ yr versus $7.5 \pm$ $4.1 \%$ for studies $>7 \mathrm{yr}$ ). Despite these relatively weak and conflicting results, a visual analysis for the length of study for both properties indicates an increased effect with longer experiments (Fig. 2). When analyzing the data in this way, it becomes apparent that most response ratios for experiments in place for longer than $10 \mathrm{yr}$ increased values for both porosity $(n=11$, from 6 of 16 total studies) and field capacity ( $n=17$ from 9 of 14 total studies).

Across the four different categories of continuous living cover practices, there was evidence of improvements in both hydrologic properties analyzed (Fig. 3a, 3b). There were not significant differences between any of the practice categories (data not shown). Overall, there were fewer studies that compared managed forestry systems to annual cropping systems and those studies did not report consistent effects on porosity and field capacity. Livestock were included in both the agroforestry and perennial grass categories and tended to have a positive effect overall on field capacity, but not porosity (Fig. 1b, 1c). It should be noted, however, that the porosity response ratios for perennial grasses were strongly influenced by several negative response ratios in the Raczkowski et al. (2012) experiment (noted with circles in Fig. 3a), where the authors describe that the tilled annual cropping system had much higher total porosity than the other treatments, including a forested plantation and pasture (the control treatment for this analysis was an average of no-till and conventionally-tilled annual cropping systems). In this study, 
the authors also note that across all of their treatments, porosity decreased over the experimental period of $8 \mathrm{yr}$.

Because of the important role that soil texture can have on how agricultural management changes soil properties, we conducted additional analysis to better reveal the impact of sand and clay contents. Further, given the oversize effect of the Raczkowski et al. (2012) study, we excluded it from this more detailed analysis. From this subset of the data ( $n=69$ from 26 studies) response ratios for both porosity and field capacity tended to increase slightly as the percent of sand increased (Fig. 4a). Subsequently, as clay content decreased, the effect of continuous living cover practices on the two properties decreased slightly (Fig. 4b). Given these relationships, it is likely that the Raczkowski et al.
(2012) experiment, which had sandier soils, muted the effect of texture on porosity when the studies were grouped together as depicted in Fig. 1b.

Further analysis into the dataset provided additional confidence to our results. Histograms for different effect sizes did not reveal any evidence of publication bias (i.e., bias against publication of experiments reporting no change in either porosity or field capacity) as there were not fewer studies in the database reporting an effect size near zero (Fig. 5a, 5b). In addition, the results of the sensitivity analysis for the mean effects indicated that removing studies did not change the overall estimates (in direction or in terms of being statistically significant from zero) for improvements in field capacity and porosity with continuous living cover
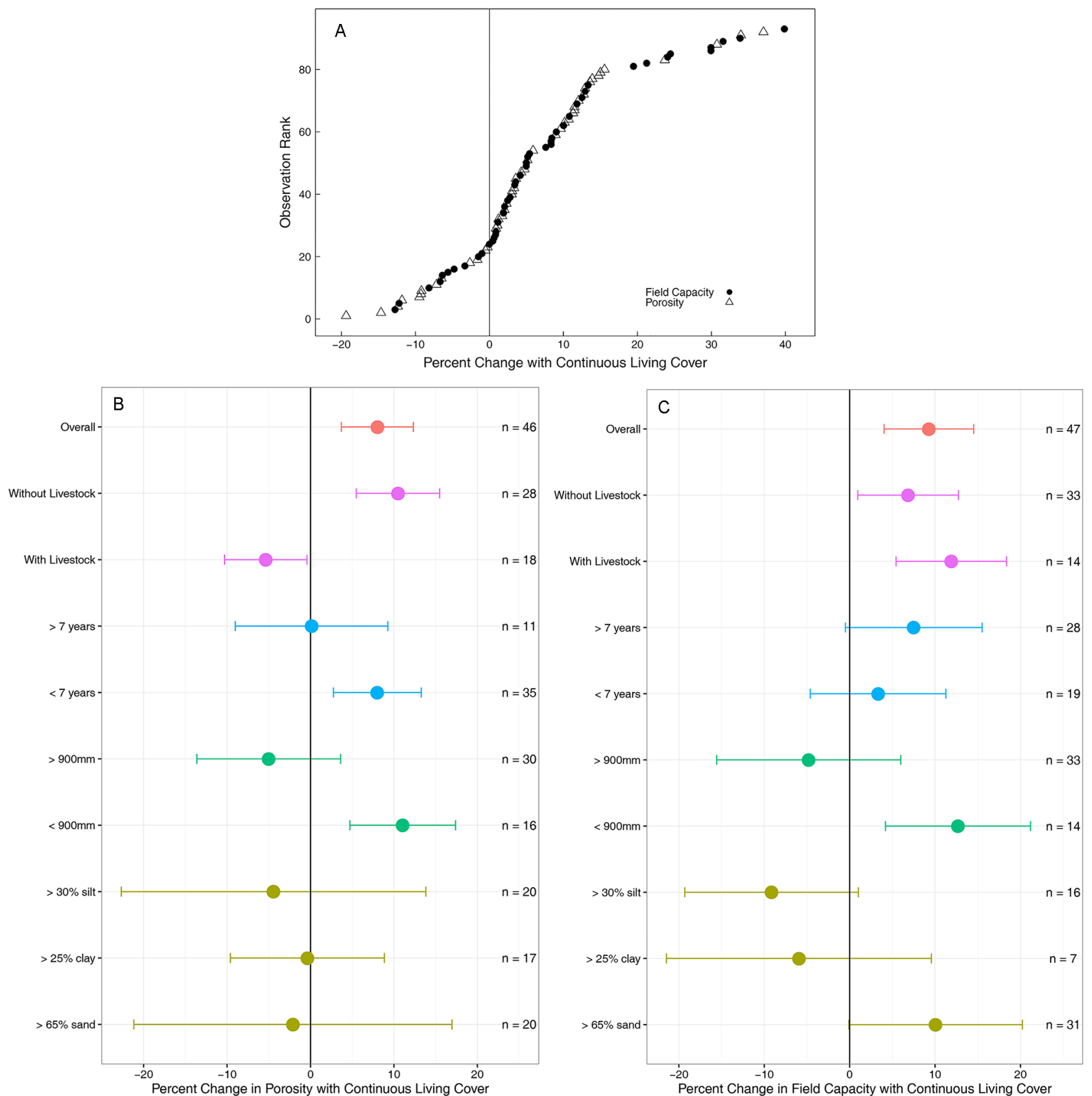

Fig. 1. (a) Overall distribution of response ratios for all of the paired observations for total porosity (open triangles) and water retained at field capacity (closed circles) (b) mean effect sizes and $95 \%$ confidence intervals for total porosity changes and (c) field capacity with continuous living cover, grouped by different soil textures, length of experimental time and mean annual precipitation in experiments. 
practices (Fig. 6a, 6b). This provides more evidence for the robust nature of the overall effect sizes (mean improvements of 8-9\% with confidence intervals of 4-15\%), where continuous living cover practices significantly increased soil hydrologic properties. The size of the dataset created smaller groupings of studies that were used to assess the effects of soil texture and study length; these smaller subgroups did not allow for a robust sensitivity analysis of these variables, but it is possible that these variables are more sensitive to removing observations. This is one reason that more field experiments evaluating these properties and practices are needed to understand the potential of continuous living cover to improve soil hydrology in different environments.

\section{DISCUSSION}

It is interesting to note the overall similarities in both direction and magnitude (means of $8-9 \%$ with $95 \%$ confidence intervals in the $4-15 \%$ range) between the studies measuring total porosity and field capacity, where only three experiments overlapped in the two databases. This could be a result of the similar physical and chemical processes impacted by the presence of living roots in the continuous living cover practices compared to the annual cropping system controls. Six et al. (2004) summarized the various mechanisms by which root-related processes influence soil structure and contribute to aggregate formation, including root penetration, root exudation and dead root decomposition. Root penetration is also understood to decrease the proportion of unstable aggregates and increase the proportion of stable aggregates (Carter et al., 1994). Further, independent of the effect that soil texture and mineralogy have on aggregation, the decomposition of root exudates is known to promote microbial activity and in turn this creates the carbon bonding agents that enhance aggregate formation (Metting, 1993; Hillel, 1998). It is through this bonding process that soil structure is improved and ultimately can facilitate better water retention and infiltration as well as deeper water flow in the soil (Bronick and Lal, 2005). Thus, measurements of porosity and the water retained at field capacity are indicators of soil aggregation which is importantly affected by the presence or absence of plant roots. While our analysis cannot separate which of these soil processes are occurring, the similar effect sizes indicate a clear positive impact that roots have on soil structure and hydrologic function.

It is important to note that there were a limited number of available studies that fit the criteria for our analysis, especially within some of the subgroups assigned for key variables. Therefore, interpretation of results is limited by characteristics of the studies that ultimately fit the criteria for inclusion; it was not possible, for example, to examine the effect of these properties across a full range of environments to more thoroughly understand the importance of soil texture and rainfall. However, the similar results from two different soil hydrologic properties, where there were very few overlapping studies between the two, provides more confidence in general direction of effects found in this analysis.

In general, our results point to some patterns as well as additional questions about how environmental factors such as rainfall

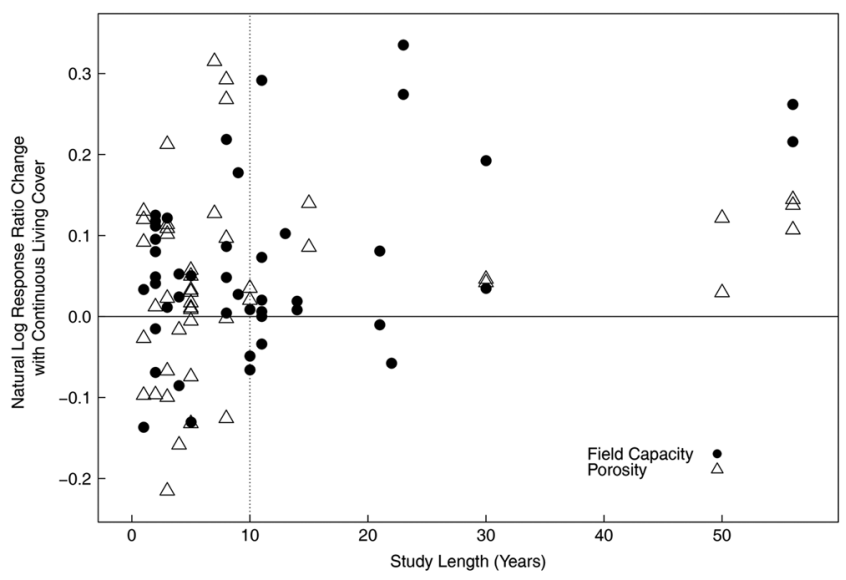

Fig. 2. Analysis of the study length for the natural log of response ratios (above zero as noted by the solid line indicates a positive effect of continuous living cover) for total porosity (open triangles) and field capacity (closed circles). The majority of studies for both properties that were in place for greater than $10 \mathrm{yr}$ (dotted line) had a positive response ratio, indicating an improvement with time that continuous living cover practices were in place.

and soil texture modulate the impact of continuous living cover practices on soil hydrology. The consistent effect in regions with less rainfall indicates that the impact of continuous living cover practices may be particularly reliable in drier areas, or that these areas are more sensitive to management changes. Although there is a less clear effect of soil texture, our results suggest a possible greater relative response to continuous living cover practices in more coarsely textured soils. We hypothesized that the opposite might be true and that there could be a greater effect in more finely textured clay soils, as it is understood that management changes affecting macroaggregation are more sensitive in clay soils relative to sandier soils; given the composition of smaller soil particles, clay soils are thought to have a more receptive soil matrix to aggregating forces such as those associated with root decomposition (Tisdall and Oades, 1982; Oades, 1993). Further to this point, Wills et al. (2017) recently proposed an "ecological site" framework to describe the potential that various land and soil types have for regeneration through management. In their analysis, they note the effect of decades of rangeland management compared to conventionally tilled annual crop systems in two different soils (one a sandier loam and another with more clay) and describe that the improvement in aggregate stability was far larger in the clay versus sandy loam soil (Wills et al., 2017).

The impact of livestock on the two properties is one contrasting aspect of this analysis; field capacity improved when continuous living cover plant practices were paired with livestock, and porosity did not. This could be a result of the slightly different underlying factors that contribute to these measurements. Field capacity is impacted by soil texture, the type of clay content in the soil, soil structure and organic matter (Hillel, 1998). Total porosity is also impacted by these factors but is likely to be relatively more sensitive to impacts from compaction. Thus, the negative effect of livestock on porosity is a possible result of compaction from animal grazing that offsets some of the benefits of managing for perennial versus annual plants. Further, 

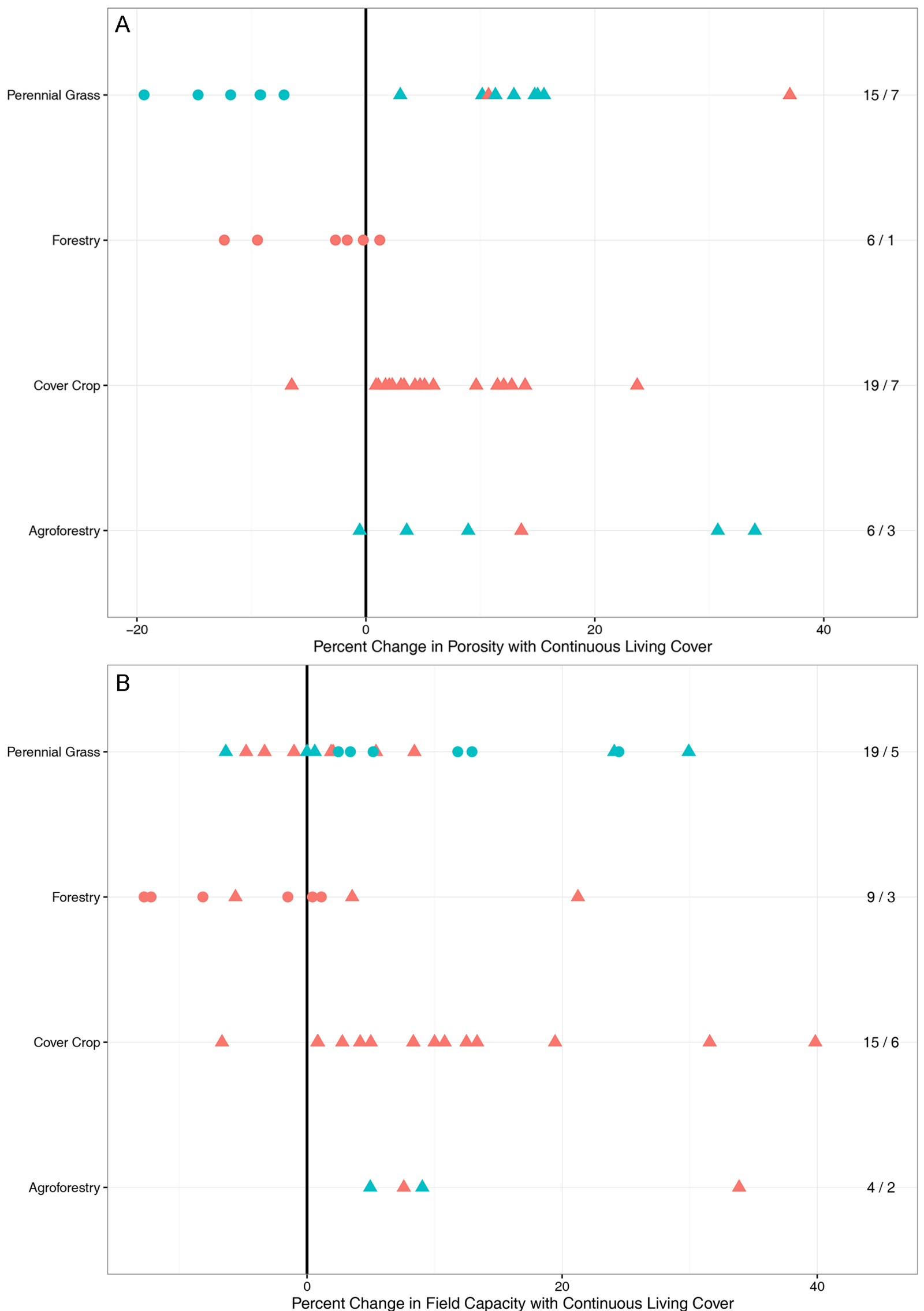

Fig. 3. Distribution of the change in (a) porosity and (b) field capacity with continuous living cover, separated by the four categories of practices considered in this analysis. Experimental treatments that included livestock are noted in blue, while those without livestock are in red. The number of observations and studies are listed on the right. Circles designate observations from the Raczkowski et al. (2012) study, which led to lower porosity values, particularly in the observations that included livestock. 
the positive effect in field capacity could be related to additional organic matter in the systems with livestock (i.e., from direct manure additions), which might offer some compensation of effects related to compaction. Due to the limited number of studies that met the criteria for the database, other key factors related to livestock grazing, such as stocking rates or management styles, could not be considered. These more detailed management variables are important to determining the net effects of animals on landscapes, thus our analysis only offers insights into general trends of the current literature. Additional research will be needed to gain a clearer sense for the possible effects of livestock and grazing systems more generally on soil water properties.

We hypothesized that there would be a greater effect of continuous living cover practices in experiments that had treatments in place for a longer period, and several studies included in the analysis did observe such trends (Schwartz et al., 2003; Ketema and Yimer, 2014). While our results were inconclusive, they did reveal a trend suggesting that experiments in place for longer (e.g., $>10 \mathrm{yr}$ ) are more likely to lead to improvements in soil hydrology. Prior analyses indicate that the experiment duration is related to improvements in soil carbon, and this could in turn lead to greater water improvements given the relationship of soil carbon
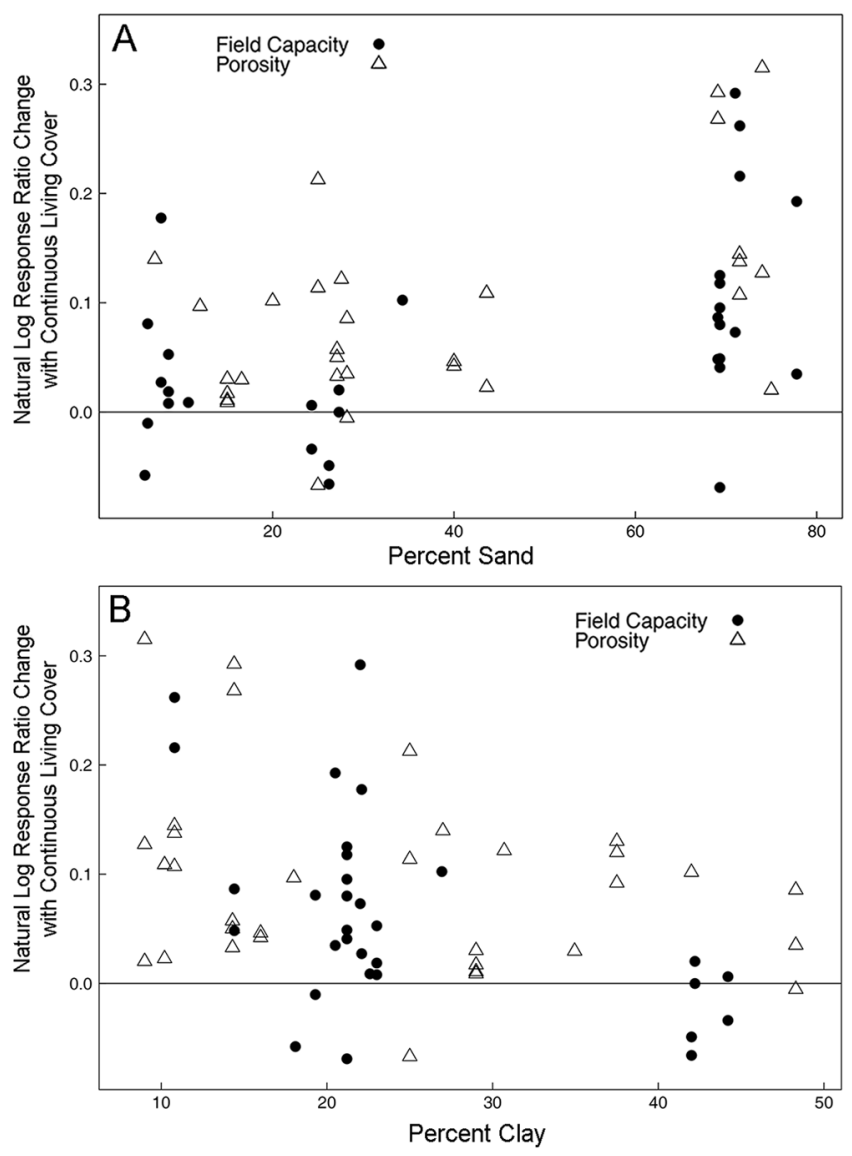

Fig. 4. Regression analysis for the (a) percent sand and (b) percent clay at different experimental sites for the natural log of response ratios (above zero as noted by the solid line indicates a positive effect of continuous living cover) for total porosity (open triangles) and field capacity (closed circles). This analysis excluded the Raczkowski et al. (2012) experiment which was found to have a large effect on the results shown in Fig. 1 b. to water holding capacity (Hudson, 1994; Emerson, 1995). A meta-analysis of cover crop impacts on soil carbon found that greater increases in carbon coincided with experiments that included cover crops for longer periods of time (Poeplau and Don; 2015). A similar effect was found in a meta-analysis evaluating the impact of no-till compared to full inversion tillage, where there was a relationship between increased soil carbon and the duration of the experiment (Angers and Eriksen-Hamel, 2008). Additional long-term studies would be beneficial to understand the effect of experiment duration on these hydrologic properties.

Improving scientific understanding of relationships between soil water, organic matter or soil carbon, and their relationships to management is of particular interest. While outside of the scope of this study, it is important to note that there is a body of literature linking soil texture and organic matter to the less frequently measured soil hydrologic properties (such as through pedotransfer functions or similar approaches) (da Silva and Kay, 1997; Kay, 1998; Wösten et al., 2001; Saxton and Rawls, 2006). However, the complex interactions of agricultural management with soil processes have proven difficult to tease out. It is possible that decreases in porosity and field capacity from continuous living cover practices are a result of root priming, where rates of carbon decomposition are known to increase in response to root exudates (Stockmann et al., 2013). Six et al. (2004) also note that there can be negative short term effects of plant growth on porosity because as roots penetrate the soil they can reduce macropores;
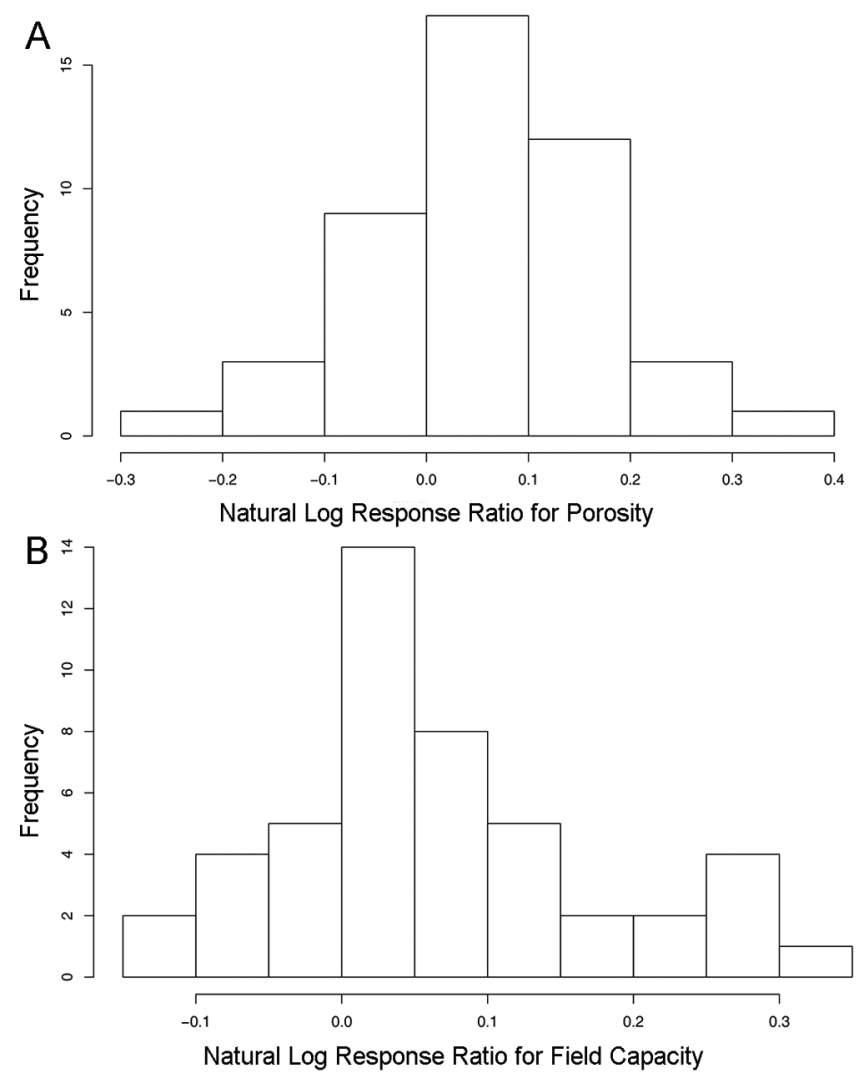

Fig. 5. Histograms for the frequency of observations of (a) porosity response ratios and (b) field capacity response ratios to evaluate publication bias. These did not indicate that there was a bias against publishing studies with an effect size around zero. 
however, that other studies have found such an effect to be offset as plant growth continues (Monroe and Kladivko, 1987). Other researchers describe that there is not consensus in the literature on the significance of root inputs on improving soil carbon levels (Stockmann et al., 2013). While more research is clearly needed, our findings offer encouragement that the benefits of some land management practices may be reflected similarly in two commonly measured soil water variables.

An advantage of identifying reliable proxies for soil health (and water in particular) that are sensitive to management is that these properties could be more widely measured and potentially used to infer a broader suite of soil properties and outcomes. Soil water or soil moisture on its own is difficult to use as a proxy for soil health, particularly at a landscape scale, because of field-level soil variability as well as the sensitivity of soil water conditions to localized variability in rainfall. However, in this analysis we evaluated the relative differences of management on a field scale, and detected positive improvements on soil water properties from continuous living cover management. While not directly
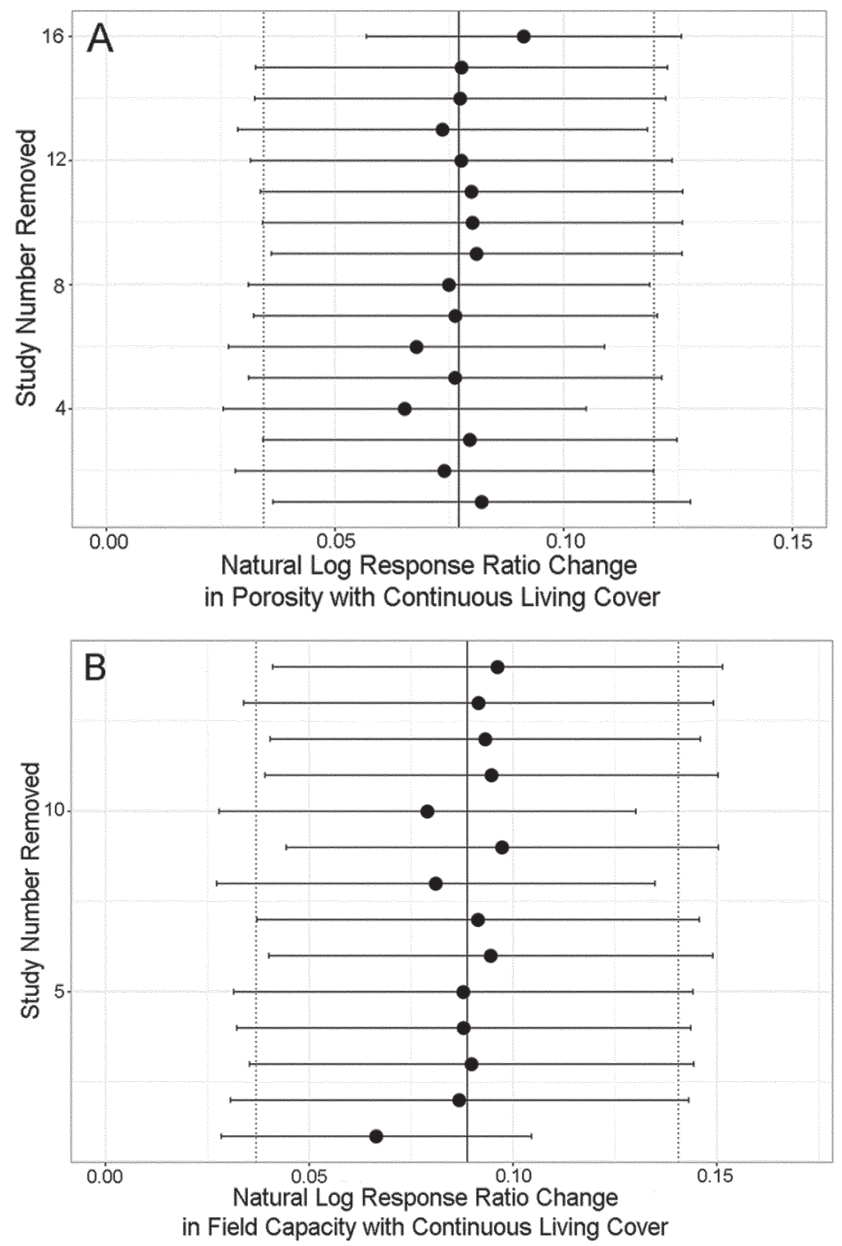

Fig. 6. Results of the Jackknife analysis to assess sensitivity of the analysis to study inclusion. The $x$ axis notes the change in mean effect size and revised $95 \%$ confidence intervals as individual studies were removed ( $y$ axis). The original overall mean effect is represented by the solid line and dotted lines the original $\mathbf{9 5} \%$ confidence intervals. Removing any individual study did not change the statistical significance of the mean effect size for (a) porosity or (b) field capacity, as no error bars crossed zero when individual studies were removed. transferable to a landscape scale, this research provides a foundation for future aggregated analyses or modeling studies which incorporate soil hydrological properties, and can help discern the links between management and hydrologic processes beyond the field scale.

\section{CONCLUSION}

Overall this analysis finds that in experiments where continuous living cover was compared to annual cropping systems, total porosity and the water retained at field capacity improved significantly. The effect was greater in drier environments $(<900 \mathrm{~mm}$ annual rainfall) for both properties, and there was some evidence to indicate that experiments with sandier soils ( $>65 \%$ sand) lead to slightly greater improvements. The effect of study length was inconclusive, but there could be a trend toward greater improvements with time. In our database, we found that studies with treatments in place for over $10 \mathrm{yr}$ were more likely to exhibit a positive effect on soil water properties. The presence or absence of livestock did not have a clear effect, likely because additional details on management (such as stocking rates and management strategies) could not be investigated with the limited dataset. Our results indicate the opportunity to improve soil water conditions through continuous living cover practices. Therefore, there is a strong need for additional long term and well-replicated experiments to better quantify the effects of these practices on soil water properties, across a range of climates, soil types, and ecosystems.

\section{ACKNOWLEDGMENTS}

We would like to thank the Union of Concerned Scientists Kendall Fellowship Program, as well as the TomKat Foundation and the Grantham Foundation for the Protection of the Environment, for funding that supported the authors while writing this article. We would also like to thank Aaron Daigh for feedback on earlier versions of this work.

\section{REFERENCES}

Abdollahi, L., and L.J. Munkholm. 2014. Tillage system and cover crop effects on soil quality: I. Chemical, mechanical, and biological properties. Soil Sci. Soc. Am. J. 78(1):262-270. doi:10.2136/sssaj2013.07.0301

Abu, S.T. 2013. Evaluating long-term impact of land use on selected soil physical quality indicators. Soil Res. 51(6):471-476. doi:10.1071/SR12360

Adams, D., J. Gurevitch, and M. Rosenberg. 1997. Resampling tests for metaanalysis of ecological data. Ecology 78:1277-1283. doi:10.1890/00129658(1997)078[1277:RTFMAO]2.0.CO;2

Amundson, R., A.A. Berhe, J.W. Hopmans, C. Olson, A.E. Sztein, and D.L. Sparks. 2015. Soil and human security in the 21st century. Science 348:1261071-1-1261071-6. doi:10.1126/science. 1261071

Andrews, S.S., D.L. Karlen, and C.A. Cambardella. 2004. The soil management assessment framework. Soil Sci. Soc. Am. J. 68(6):1945-1962. doi:10.2136/sssaj2004.1945

Angers, D.A., and N.S. Eriksen-Hamel. 2008. Full-inversion tillage and organic carbon distribution in soil profiles: A meta-analysis. Soil Sci. Soc. Am. J. 72(5):1370-1374. doi:10.2136/sssaj2007.0342

Basche, A.D., T.C. Kaspar, S.V. Archontoulis, D.B. Jaynes, T.J. Sauer, T.B. Parkin, and F.E. Miguez. 2016. Soil water improvements with the long-term use of a winter rye cover crop. Agric. Water Manage. 172:40-50. doi:10.1016/j. agwat.2016.04.006

Bronick, C.J., and R. Lal. 2005. Soil structure and management: A review. Geoderma 124:3-22. doi:10.1016/j.geoderma.2004.03.005

Carter, M.R., D.A. Angers, and H.T. Kunelius. 1994. Soil structural form and stability, and organic matterundercool-season perennialgrasses. SoilSci.Soc. Am. J. 58:1194-1199. doi:10.2136/sssaj1994.03615995005800040027x 
Carof, M., S. De Tourdonnet, Y. Coquet, V. Hallaire, and J. Roger-Estrade. 2007. Hydraulic conductivity and porosity under conventional and no-tillage and the effect of three species of cover crop in northern France. Soil Use Manage. 23(3):230-237. doi:10.1111/j.1475-2743.2007.00085.x

Chisci, G.C., P. Bazzoffi, M. Pagliai, R. Papini, S. Pellegrini, and N. Vignozzi. 2001. Association of sulla and atriplex shrub for the physical improvement of clay soils and environmental protection in central Italy. Agric. Ecosyst. Environ. 84(1):45-53. doi:10.1016/S0167-8809(00)00190-0

Chandrasoma, J.M., R.P. Udawatta, S.H. Anderson, A.L. Thompson, and M.A. Abney. 2016. Soil hydraulic properties as influenced by prairie restoration. Geoderma 283:48-56. doi:10.1016/j.geoderma.2016.08.001

da Silva, A.P., and B.D. Kay. 1997. Estimating the least limiting water range of soils from properties and management. Soil Sci. Soc. Am. J. 61(3):877883. doi:10.2136/sssaj1997.03615995006100030023x

Eldridge, D.J., A.G.B. Poore, M. Ruiz-Colmenero, M. Letnic, and S. Soliveres. 2016. Ecosystem structure, function and composition in rangelands are negatively affected by livestock grazing. Ecol. Appl. 26(4):1273-1283. doi: $10.1890 / 15-1234$

Emerson, W. 1995. Water-retention, organic-C and soil texture. Soil Res. 33:241-251. doi:10.1071/SR9950241

Garcia, R.A., Y. Li, and C.A. Rosolem. 2013. Soil organic matter and physical attributes affected by crop rotation under no-till. Soil Sci. Soc. Am. J. 77(5):1724-1731. doi:10.2136/sssaj2012.0310

Greminger, P.J., Y.K. Sud, and D.R. Nielsen. 1985. Spatial variability of fieldmeasured soil-water characteristics. Soil Sci. Soc. Am. J. 49(5):1075-1082. doi: $10.2136 /$ sssaj1985.03615995004900050001x

Haghighi, F., M. Gorji, and M. Shorafa. 2010. A study of the effects of land use changes on soil physical properties and organic matter. Land Degrad. Dev. 21(5):496-502. doi:10.1002/ldr.999

Hedges, L., J. Gurevitch, and P. Curtis. 1999. The meta- analysis of response ratios in experimental ecology. Ecology 80(4):1150-1156. doi:10.1890/00129658(1999)080[1150:TMAORR]2.0.CO;2

Hillel, D. 1998. Environmental soil physics: Fundamentals, applications, and environmental considerations. Academic Press, San Diego, CA.

Hudson, B. 1994. Soil organic matter and water holding capacity. J. Soil Water Conserv. 49:189-194.

IPCC. 2013. Summary for Policymakers. In: T.F. Stocker, D. Qin, G.-K. Plattner, M. Tignor, S.K. Allen, J. Boschung, A. Nauels, Y. Xia, V. Bex, and P.M. Midgley, editors, Climate Change 2013: The physical science basis. Contribution of Working Group I to the Fifth Assessment Report of the Intergovernmental Panel on Climate Change. Cambridge Univ. Press, Cambridge and New York.

Jägermeyr, J., D. Gerten, S. Schaphoff, J. Heinke, W. Lucht, and J. Rockström. 2016. Integrated crop water management might sustainably halve the global food gap. Environ. Res. Lett. 11(2):025002. doi:10.1088/1748$9326 / 11 / 2 / 025002$

Jiang, P., S.H. Anderson, N.R. Kitchen, E.J. Sadler, and K.A. Sudduth. 2007. Landscape and conservation management effects on hydraulic properties of a claypan-soil toposequence. Soil Sci. Soc. Am. J. 71(3):803-811. doi: $10.2136 /$ sssaj2006.0236

Jordan, N., and K.D. Warner. 2010. Enhancing the multifunctionality of US agriculture. BioScience 60(1):60-66. doi:10.1525/bio.2010.60.1.10

Kay, B. 1998. Soil structure and organic carbon: A review. In: R. Lal, J.M. Kimble, R.F. Follett, and B.A. Stewart, editors, Soil processes and the carbon cycle. Vol. 11. CRC Press, Boca Raton, FL. p. 169-197.

Keisling, T.C., H.D. Scott, B.A. Waddle, W. Williams, and R.E. Frans. 1994. Winter cover crops influence on cotton yield and selected soil properties. Commun. Soil Sci. Plant Anal. 25:3087-3100. doi: $10.1080 / 00103629409369250$

Ketema, H., and F. Yimer. 2014. Soil property variation under agroforestry based conservation tillage and maize based conventional tillage in Southern Ethiopia. Soil Tillage Res. 141:25-31. doi:10.1016/j.still.2014.03.011

Levi, M.R., J.N. Shaw, C.W. Wood, S.M. Hermann, E.A. Carter, and Y. Feng. 2010. Land management effects on near-surface soil properties of southeastern US coastal plain Kandiudults. Soil Sci. Soc. Am. J. 74(1):258-271. doi:10.2136/sssaj2009.0015

Li, X., F. Li, R. Zed, Z. Zhan, and B. Singh. 2007. Soil physical properties and their relations to organic carbon pools as affected by land use in an alpine pastureland. Geoderma 139:98-105. doi:10.1016/j. geoderma.2007.01.006
Mahmood-ul-Hassan, M., E. Rafique, and A. Rashid. 2013. Physical and hydraulic properties of aridisols as affected by nutrient and crop-residue management in a cotton-wheat system. Acta Sci. Agron. 35(1):127-137. doi:10.4025/actasciagron.v35i1.14683

Mele, P.M., I.A.M. Yunusa, K.B. Kingston, and M.A. Rab. 2003. Response of soil fertility indices to a short phase of Australian woody species, continuous annual crop rotations or a permanent pasture. Soil Tillage Res. 72(1):2130. doi:10.1016/S0167-1987(03)00063-1

Menne, M.J., I. Durre, R.S. Vose, B.E. Gleason, and T.G. Houston. 2012. An overview of the Global Historical Climatology Network-Daily database. J. Atmos. Ocean. Technol. 29(7):897-910. doi:10.1175/JTECH-D-11-00103.1

Metting, F.B., Jr., editor. 1993. Soil microbial ecology: Applications in agricultural and environmental management. Marcel Dekker, New York.

Moebius-Clune, B.N., D.J. Moebius-Clune, B.K. Gugino, O.J. Idowu, R.R. Schindelbeck, A.J. Ristow, H.M. van Es, J.E. Thies, H.A. Shayler, M.B. McBride, D.W. Wolfe, and G.S. Abawi. 2016. Comprehensive assessment of soil health-Cornell Framework Manual, edition 3.1. Cornell University, Geneva, NY.

Møller, A.P., and M.D. Jennions. 2001. Testing and adjusting for publication bias. Trends Ecol. Evol. 16:580-586. doi:10.1016/S0169-5347(01)02235-2

Monroe, C.D., and E.J. Kladivko. 1987. Aggregate stability of a silt loam as affected by roots of corn, soybeans and wheat. Commun. Soil Sci. Plant Anal. 18:1077-1087. doi:10.1080/00103628709367884

Munkholm, L.J., R.J. Heck, and B. Deen. 2013. Long-term rotation and tillage effects on soil structure and crop yield. Soil Tillage Res. 127:85-91. doi:10.1016/j.still.2012.02.007

Nimmo, J.R. 2004. Porosity and pore Size Distribution. In: D. Hillel, editor, Encyclopedia of soils in the environment. Vol. 3. Elsevier, London. p. 295-303.

Nyalemegbe, K.K., E.K. Asiedu, E.O. Ampontuah, A.L. Nyamekye, and S.K.A. Danso. 2011. Improving the productivity of vertisols in the Accra plains of Ghana using leguminous cover crops. Int. J. Agric. Sustain. 9(3):434-442. doi:10.1080/14735903.2011.583480

Nyamadzawo, G., P. Nyamugafata, M. Wuta, and J. Nyamangara. 2012. Maize yields under coppicing and non coppicing fallows in a fallow-maize rotation system in central Zimbabwe. Agrofor. Syst. 84(2):273-286. doi:10.1007/s10457-011-9453-9

Oades, J.M. 1993. The role of biology in the formation, stabilization and degradation of soil structure. Geoderma 56:377-400. doi:10.1016/00167061(93)90123-3

Patrick, W.H., C.B. Haddon, and J.A. Hendrix. 1957. The effect of longtime use of winter cover crops on certain physical properties of Commerce loam. Soil Sci. Soc. Am. J. 21(4):366-368. doi:10.2136/ sssaj1957.03615995002100040004x

Poeplau, C., and A. Don. 2015. Carbon sequestration in agricultural soils via cultivation of cover crops-A meta-analysis. Agric. Ecosyst. Environ. 200(1):33-41. doi:10.1016/j.agee.2014.10.024

Pryor, S.C., D. Scavia, C. Downer, M. Gaden, L. Iverson, R. Nordstrom, J. Patz, and G.P. Robertson. 2014. Ch. 18: Midwest. In: J.M. Melillo, T. Richmond, and G.W. Yohe, editors, Climate change impacts in the United States: The Third National Climate Assessment. US Global Change Research Program, Washington DC.

Philibert, A., C. Loyce, and D. Makowski. 2012. Assessment of the quality of meta-analysis in agronomy. Agric. Ecosyst. Environ. 148:72-82. doi:10.1016/j.agee.2011.12.003

R Core Team. 2016. R: A language and environment for statistical computing. Version 1.0.136, 2009-2016. R Foundation for Statistical Computing. http://www.R-project.org (verified 9 Sept. 2017).

Raczkowski, C.W., J.P. Mueller, W.J. Busscher, M.C. Bell, and M.L. Mcgraw. 2012. Soil physical properties of agricultural systems in a large-scale study. Soil Tillage Res. 119:50-59. doi:10.1016/j.still.2011.12.006

Rosenberg, M., D. Adams, J. Gurevitch. 2000. MetaWin: Statistical Software for Meta-Analysis. Version 2.0.

Rost, S., D. Gerten, H. Hoff, W. Lucht, M. Falkenmark, and J. Rockström. 2009. Global potential to increase crop production through water management in rainfed agriculture. Environ. Res. Lett. 4(4):044002. doi:10.1088/17489326/4/4/044002

Russo, D., and E. Bresler. 1981. Soil hydraulic properties as stochastic processes: I. An analysis of field spatial variability. Soil Sci. Soc. Am. J. 45(4):682687. doi:10.2136/sssaj1981.03615995004500040002x 
Sasal, M.C., M.G. Castiglioni, and M.G. Wilson. 2010. Effect of crop sequences on soil properties and runoff on natural-rainfall erosion plots under no tillage. Soil Tillage Res. 108:24-29. doi:10.1016/j.still.2010.03.010

Saxton, K.E., and W.J. Rawls. 2006. Soil water characteristic estimates by texture and organic matter for hydrologic solutions. Soil Sci. Soc. Am. J. 70(5):1569-1578. doi:10.2136/sssaj2005.0117

Schwartz, R.C., S.R. Evett, and P.W. Unger. 2003. Soil hydraulic properties of cropland compared with reestablished and native grassland. Geoderma 116:47-60. doi:10.1016/S0016-7061(03)00093-4

Silva, G.L., H.V. Lima, M.M. Campanha, R.J. Gilkes, and T.S. Oliveira. 2011. Soil physical quality of Luvisols under agroforestry, natural vegetation and conventional crop management systems in the Brazilian semi-arid region. Geoderma 167-168:61-70. doi:10.1016/j.geoderma.2011.09.009

Six, J., H. Bossuyt, S. Degryze, and K. Denef. 2004. A history of research on the link between (micro) aggregates, soil biota, and soil organic matter dynamics. Soil Tillage Res. 79(1):7-31. doi:10.1016/j.still.2004.03.008

Soil Survey Staff. 2012. Web soil survey. USDA Natural Resources Conservation Service, Washington, DC. http://websoilsurvey.nrcs.usda.gov/.

Sposito, G. 2013. Green water and global food security. Vadose Zone J. 12(4). doi:10.2136/vzj2013.02.0041

Stockmann, U., M.A. Adams, J.W. Crawford, D.J. Field, N. Henakaarchchi, M. Jenkins, B. Minasny, A.B. McBratney, V.D.R. de Courcelles, K. Singh, and I. Wheeler. 2013. The knowns, known unknowns and unknowns of sequestration of soil organic carbon. Agric. Ecosyst. Environ. 164:80-99. doi:10.1016/j.agee.2012.10.001

St. Pierre, N.R. 2001. Invited Review: Integrating quantitative findings from multiple studies using mixed model methodology. J. Dairy Sci. 84(4):741755. doi:10.3168/jds.S0022-0302(01)74530-4

Stewart, B., and G. Peterson. 2015. Managing green water in dryland agriculture. Agron. J. 107:1544-1553. doi:10.2134/agronj14.0038
Tisdall, J.M., and J.M. Oades. 1982. Organic matter and water-stable aggregates in soils. Eur. J. Soil Sci. 33(2):141-163. doi:10.1111/j.1365-2389.1982. tb01755.x

USDA-NRCS. 2016. Soil health literature database. USDA Natural Resources Conservation Service. http://www.nrcs.usda.gov/wps/portal/nrcs/ detailfull/soils/health/?cid=stelprdb1257753 (accessed 20 Sept. 2016).

Walia, M.K., S.S. Walia, and S.S. Dhaliwal. 2010. Long-term effect of integrated nutrient management of properties of Typic Ustochrept after 23 cycles of an irrigated rice (Oryza sativa L.) -wheat (Triticum aestivum L.) system. J. Sustain. Agric. 34(7):724-743. doi:10.1080/10440046.2010.507519

Wills, S., C. Williams, C. Seybold, L. Scheffe, Z. Libohova, D. Hoover, C. Talbot, and J. Brown. 2017. Using soil survey to assess and predict soil condition and change. In: D. Field, C. Morgan, and A. McBratney, editors, Global soil security. Springer International, New York. p. 123-135. doi:10.1007/9783-319-43394-3_11

Wilson, G.F., R. Lal, and B.N. Okigbo. 1982. Effects of cover crops on soil structure and on yield of subsequent arable crops grown under strip tillage on an eroded Alfisol. Soil Tillage Res. 2(3):233-250. doi:10.1016/01671987(82)90013-7

Wösten, J.H.M., Y.A. Pachepsky, and W.J. Rawls. 2001. Pedotransfer functions: Bridging the gap between available basic soil data and missing soil hydraulic characteristics. J. Hydrol. 251(3-4):123-150. doi:10.1016/ S0022-1694(01)00464-4

Villamil, M.B., G.A. Bollero, R.G. Darmody, F.W. Simmons, and D.G. Bullock. 2006. No-till corn/soybean systems including winter cover crops. Soil Sci. Soc. Am. J. 70(6):1936-1944. doi:10.2136/sssaj2005.0350

Yu, M., L. Zhang, X. Xu, K-H. Feger, Y. Wang, W. Liu, and K. Schwärzel. 2015. Impact of land-use changes on soil hydraulic properties of Calcaric Regosols on the Loess Plateau, NW China. J. Plant Nutr. Soil Sci. 178(3):486-498. doi:10.1002/jpln.201400090 